\title{
Shallow-water Aplysina Nardo (Aplysinidae, Verongida, Demospongiae) from the São Sebastião Channel and its environs (Tropical southwestern Atlantic), with the description of a new species and a literature review of other brazilian records of the genus
}

\author{
Ulisses dos Santos Pinheiro ${ }^{1,2}$ \\ Eduardo Hajdu 1, 3
}

\begin{abstract}
Two species of Aplysina Nardo, 1834 are described in this article, Aplysina caissara sp. $\mathbf{n}$. and $A$. fulva (Pallas, 1766). Additionally, a possible third species was identified as $A$. aff. cauliformis. Collections were done in the São Sebastião Channel area as an ongoing effort to assess the poriferan biodiversity of the northern sector of the São Paulo State coastline. Specimens were collected by scuba diving, and descriptions of external morphology are based on the observation of populations alive, and on extensive underwater photography. A literature review of other brazilian records of Aplysina was undertaken, and an ammended species list is offered.

KEY WORDS. Porifera, Aplysina, sponges, southwestern Atlantic, taxonomy, Brazil
\end{abstract}

A qualitative survey of the sponge fauna of the São Sebastião Channel area and its environs has been conducted during the years of 1996 and 1997, revealing over 120 species (HAJDU et al. 1996, 1999; HAJDU 1998). Ongoing collecting effort is centered on yielding additional specimens of rare species, photographing intrapopulational variability in situ, and furnishing biological material for a program of chemico/pharmacological screening for bioactive natural products:

The genus Aplysina Nardo, 1834 is peculiar for its diversity gradient, richer in the Atlantic Ocean than in the Indo-Pacific, coupled to its notorious possession of brominated compounds (e.g. BERGQUIST \& WELLS 1983). These facts, coupled to uncertainties on the identification of the material originating from the study area, prompted us to start a taxonomic study of those populations.

To date, ten species of Aplysina were recorded from the Brazilian coast. Species are A. archeri (Higgins, 1875), A. capensis Carter, 1881, A. cauliformis Carter, 1882, A. fistularis (Esper, 1794), A. fulva (Pallas, 1766), A. janusi (BouryEsnault, 1973), A. lacunosa (Pallas, 1766), A. longissima Carter, 1882, A. pergamentacea Hechtel, 1983 and A. tenuissima (Hyatt, 1875). These records are reevaluated based on the senior author's experience, on discussion with colleagues, on collected,

1) Museu Nacional, Departamento de Invertebrados, Universidade do Brasil. Quinta da Boa Vista, 20940-040 Rio de Janeiro, Rio de Janeiro, Brasil.

E-mail: uli6@acd.ufrj.br or hajdu@acd.ufrj.br

2) FAPERJ fellowship.

3) CNPq fellowship. 
but yet undescribed material in both MNRJ and UFRJPOR collections, as well as on descriptions published in the literature. An ammended list of species known from the Brazilian coast will be furnished below.

\section{MATERIAL AND METHODS}

Specimens were collected during an ongoing faunistic survey conducted in the area of the São Sebastião Channel and its environs, in the municipalities of São Sebastião and Ilhabela, situated in the northern sector of São Paulo State coastline (between latitudes $23^{\circ} 44^{\prime} \mathrm{S}$ and $23^{\circ} 58^{\prime}$ 'S, approximately).

Specimens were collected by scuba diving, and photographed in situ whenever possible. An enzimatic procedure used to obtain clean preparations of spongin fibres has been used, and is described in detail below.

A sponge fragment with $1-2 \mathrm{~cm}^{3}$ was incubated in $30 \mathrm{ml}$ digestion buffer (100 mM sodium acetate, $\mathrm{pH} 5,0$; cisteine $5 \mathrm{mM} ; 5 \mathrm{mM}$ EDTA) during 24 hours at $4^{\circ} \mathrm{C}$. Subsequently, $1 \mathrm{ml}$ of a $3 \%$ papain solution (freshly made in digestion buffer) was added to the sponge digestion tube and incubated at $60^{\circ} \mathrm{C}$ for $24 \mathrm{~h}$. Later, the digested fragment was washed with water jets to separate the spongin fibers, included in wax, and cut to the desired thickness (ca. $0.5 \mathrm{~mm}$ ).

Abbreviations used are: BA (Bahia State), BMNH (The Natural History Museum, London), CE (Ceará State), ES (Espírito Santo State), MCN (Museu de Ciências Naturais, Fundação Zoobotânica do Rio Grande do Sul, Porto Alegre), MNRJ (Museu Nacional, Universidade do Brasil, Rio de Janeiro), PE (Pernambuco State), REVIZEE (Program for the Evaluation of the Sustainable Potential of Life Resources in the Exclusive Economic Zone - Brazil), RJ (Rio de Janeiro State), RN (Rio Grande do Norte State), SC (Santa Catarina State), SP (São Paulo State), UFRJPOR (Museu Nacional, Universidadedo Brasil, Rio de Janeiro), ZMA (Zoologisch Museum Amsterdam, Amsterdam).

\section{RESULTS}

\section{Verongida Bergquist, 1978 Aplysinidae Carter, 1875}

Diagnosis. Encrusting, massive, club-shaped and fan-shaped growth forms. Reticulate, anastomosing spongin fibres produce polygonal meshes in the choanosomal skeleton which are not organized into one plane. Fibres have normal bark and pith elements, without foreign detritus, and the collagenous spongin matrix is dense. Choanocyte chambers are small, spherical and diplodal (sensu VAN SOEST 1978).

\section{Aplysina Nardo, 1834}

Diagnosis. Marked aerophobic colour change from yellow or green to darker colours; only one kind of fibre is present, without foreign detritus and with a thick pith component; fibres form a regular reticulation with large hexagonal meshes and have no specialised surface arrangement (sensu BERGQUIST 1980). Type species: Aplysina aerophoba Schmidt, 1862. 


\section{Aplysina caissara sp. $\mathbf{n}$.}

Figs 1-2,4-6, Tab. I

Aplysina fistularis fulva; Mothes-de-Moraes, 1987: 133, figs 5, 9.

Aplysina fulva; Lerner, 1996: 115, figs 24, 26.

Holotype. MNRJ 1988, rocky coast between Prainha and Praia Brava

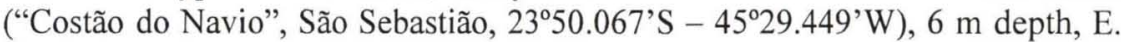
Hajdu leg., 29/I/1999.

Paratypes - MNRJ 268, Ponta Recife, (São Sebastião Channel, São Se-

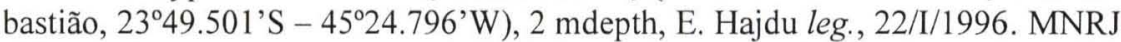
578 , southern coast of Ilha de Toque-Toque, (São Sebastião, 2351.209'S - 45 ${ }^{\circ}$ 31.600'W), 11 mdepth, E. Hajđu leg., 15/VI/1997. MNRJ 1673, Ponta do Jarobá (São Sebastião, 2349.679'S - 45²5.278'W), 4.5 mdepth, E. Hajdu leg., 22/IV/ 1998. MNRJ 1675, rocky coast between Prainha and Praia Brava ("Costão do

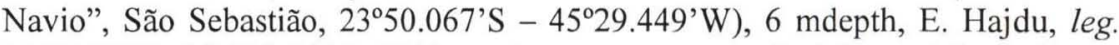
24/IV/1998. MNRJ 1989, 2013, rocky coast between Prainha and Praia Brava (“Costão do Navio", São Sebastião, 2350.067'S - 45²9.449'W), 6 m depth, E. Hajdu leg., 29/I/1999.

Schizotype - BMNH 1999.10.6.1.

Additional material. MCN 383, Ilha de João da Cunha (Porto Belo, SC), 3 m depth, S.M. Pauls leg.. MCN 1034 Ilha de João da Cunha (Porto Belo, SC), 0.5 m depth, A.A. Lise leg., 22/X/1977. MCN 1035, Ilha de João da Cunha (Porto Belo, SC), A.A. Lise leg., 06/XI/1981. MCN 2235, Saco da Mulata (Ilha da Galé, Bombinhas, SC), $12 \mathrm{~m}$ depth, C.B. Lerner leg., 14/II/1991. MCN 2278, small embayment on the SW (Ilha da Galé, Bombinhas, SC), 8 m depth, C.B. Lerner leg., 29/III/1991.

Diagnosis. Aplysina caissara $\mathbf{~ s p . ~} \mathbf{n}$. is distinguished from every other Aplysina known from the Tropical western Atlantic by a combination of bright yellow live-colour, habit with small digits topped by oscula and a delicate skeletal reticulation.

Description. Specimens can have a few (3-4, in young specimens) to many digits (25-30), which are mostly erect (Figs 1-2). Digits can be single or anastomosed, cylindrical (often; fusiform or straight) or slightly vulcaniform (rare), 2-6 $\mathrm{cm}$ high, $0.6-1.5 \mathrm{~cm}$ wide. Area coverage can be as large as $25 \times 15 \mathrm{~cm}$, but is more often about $6 \times 6 \mathrm{~cm}$. Consistency is rather compressible (cheesy). Surface is slightly conulose. Oscula are mostly apical (1.5-4 mm), but a few smaller lateral ones (ca. $1 \mathrm{~mm}$ in diametre) occur also. Live colour is bright-yellow externally and internally, which turns into deep-purple after preservation in alcohol. The holotype (Fig. 4 ) bears 10 digits, $1-2 \mathrm{~cm}$ high, $0.3-0.8 \mathrm{~cm}$ wide, and spreads 3.5 x $4.5 \mathrm{~cm}$ over a small boulder.

Skeleton (Tab. I). No ectosomal specialization. Choanosome with a delicate, irregular tridimensional poligonal network (Fig. 5) of pithed spongin fibres (Fig. 6). After preservation and preparation, fibres are yellow to brown, with a pith which is either of the same colour, or much darker, nearly black. The same specimen may have pith of both colours. Fibres are smooth, straight, curved or undulating. 
Table I. Micrometric data for the skeletal architecture of Aplysina caissara sp. n. holotype, paratypes and additional material studied (including $A$. fistularis forma fulva sensu MOTHESDE-MORAES 1987; and $A$. fulva sensu LeRNER 1996). Measures are in $\mu \mathrm{m}$ and $\mathrm{N}=20$, unless stated otherwise.

\begin{tabular}{|c|c|c|c|}
\hline Specimen & $\begin{array}{c}\text { Fibre width: } \\
\text { thinnest - mean - thickest }\end{array}$ & $\begin{array}{l}\text { Pith width: } \\
\text { thinnest - mean - thickest }\end{array}$ & $\begin{array}{l}\text { Mesh area }\left(\mathrm{mm}^{2}\right) \text { : smallest area } \\
\text { (length } \mathrm{x} \text { width) - mean area - } \\
\text { largest area (length } \mathrm{x} \text { width) }\end{array}$ \\
\hline Holotype (MNRJ 1988) & $26-\underline{48.9}-77$ & $17-\underline{36.5}-60$ & $\begin{array}{l}0.03(0.200 \times 0.150)-0.30- \\
0.83(1.040 \times 0.800)\end{array}$ \\
\hline Paratype (MNRJ 268) & $31-43.2-53$ & $17-25.3-36$ & $\begin{array}{l}0.01(0.407 \times 0.320)-0.19- \\
0.84(1.232 \times 0.679)\end{array}$ \\
\hline Paratype (MNRJ 578) & $31-43.2-53$ & $19-31.3-41$ & $\begin{array}{l}0.06(0.262 \times 0.233)-0.17- \\
0.41(0.873 \times 0.475)\end{array}$ \\
\hline Paratype (MNRJ 1673) & $34-54.0-75$ & $23-32.0-52$ & $\begin{array}{l}0.09(0.306 \times 0.294)-0.36- \\
0.62(1.017 \times 0.612)\end{array}$ \\
\hline Paratype (MNRJ 1675) & $41-\underline{57.7}-86$ & $22-35.5-53$ & $\begin{array}{l}0.06(0.339 \times 0.175)-0.10- \\
0.55(0.989 \times 0.553)\end{array}$ \\
\hline Paratype (MNRJ 1989) & $26-\underline{42.9}-50$ & $19-27.1-36$ & $\begin{array}{l}0.03(0.220 \times 0.140)-0.31- \\
0.74(1.040 \times 0.710)\end{array}$ \\
\hline Paratype (MNRJ 2013) & $26-\underline{45.5}-50$ & $17-\underline{32.9}-41$ & $\begin{array}{l}0.09(0.320 \times 0.290)-0.27- \\
0.46(0.790 \times 0.580\end{array}$ \\
\hline $\mathrm{MCN} 383$ & $37-54.0-80$ & $26-38.0-60$ & $\begin{array}{l}0.05(0.232 \times 0.232)-0.30- \\
0.76(0.882 \times 0.857)\end{array}$ \\
\hline MCN 1034 & $43-\underline{56.0}-89$ & $20-34.0-66$ & $\begin{array}{l}0.15(0.422 \times 0.367)-0.18- \\
1.31(1.531 \times 0.857)\end{array}$ \\
\hline MCN 1035 & $34-\underline{58.0}-92$ & $20-\underline{43.0}-75$ & $\begin{array}{l}0.11(0.380 \times 0.282)-0.18- \\
0.81(0.919 \times 0.882)\end{array}$ \\
\hline MCN 2275 & $43-\underline{660}-121$ & $29-\underline{48.0}-98$ & $\begin{array}{l}0.10(0.465 \times 0.220)-0.71- \\
0.70(0.955 \times 0.735)\end{array}$ \\
\hline MCN 2278 & $49-\underline{69.0}-101$ & $29-\underline{49.0}-78$ & $\begin{array}{l}0.13(0.429 \times 0.306)-\underline{0.36}- \\
1.09(1.433 \times 0.759)\end{array}$ \\
\hline
\end{tabular}

Ecology. The species has a typically patchy distribution, being often very rare, but reaching reazonable densities at a few spots (e.g. type locality), where specimens can be found every couple of meters. Its known depth distribution is from 0.5 to 12 meters, and the geographical distribution is at present confined between the coasts of São Paulo and Santa Catarina states, from ca. $23^{\circ} 49^{\prime}$ to $27^{\circ} 10^{\prime} \mathrm{S}$.

Although a few specimens were seen at very shallow depths $(0.5-3 \mathrm{~m})$ in places of somewhat restricted water flow, where temperatures may reach $28^{\circ} \mathrm{C}$, most of them are located in areas of large water circulation, exposed to the common arrival of Central South Atlantic Waters, when temperatures reach minima around $13^{\circ} \mathrm{C}$.

Etymology. The species is named after the people inhabiting the southeastern, and part of the southern Brazilian Coastline, the "caiçaras".

Remarks. Dozens of specimens were seen in the field, especially in the vicinity of the type locality. Many were photographed in situ (Figs 1-2), and the images used to help circunscribe the species better.

Aplysina caissara sp. $\mathbf{n}$. is the only species in the genus known to combine a collection of small erect digits with apical oscula and a bright yellow colour in life, with an overall small size. Additionally, its reticulation is rather delicate, with slender fibres and smaller meshes, with variably coloured pith. Aplysina fulva,

Figs 1-3. Aplysina spp. in situ in the São Sebastião Channel area. (1-2) $A$. caissara sp. $\mathbf{n}$. (specimens not collected); (3) A. aff. cauliformis (MNRJ 1674) - scale bar is $2 \mathrm{~cm}$ long.

Revta bras. Zool. 18 (Supl. 1): 143 - 160, 2001 

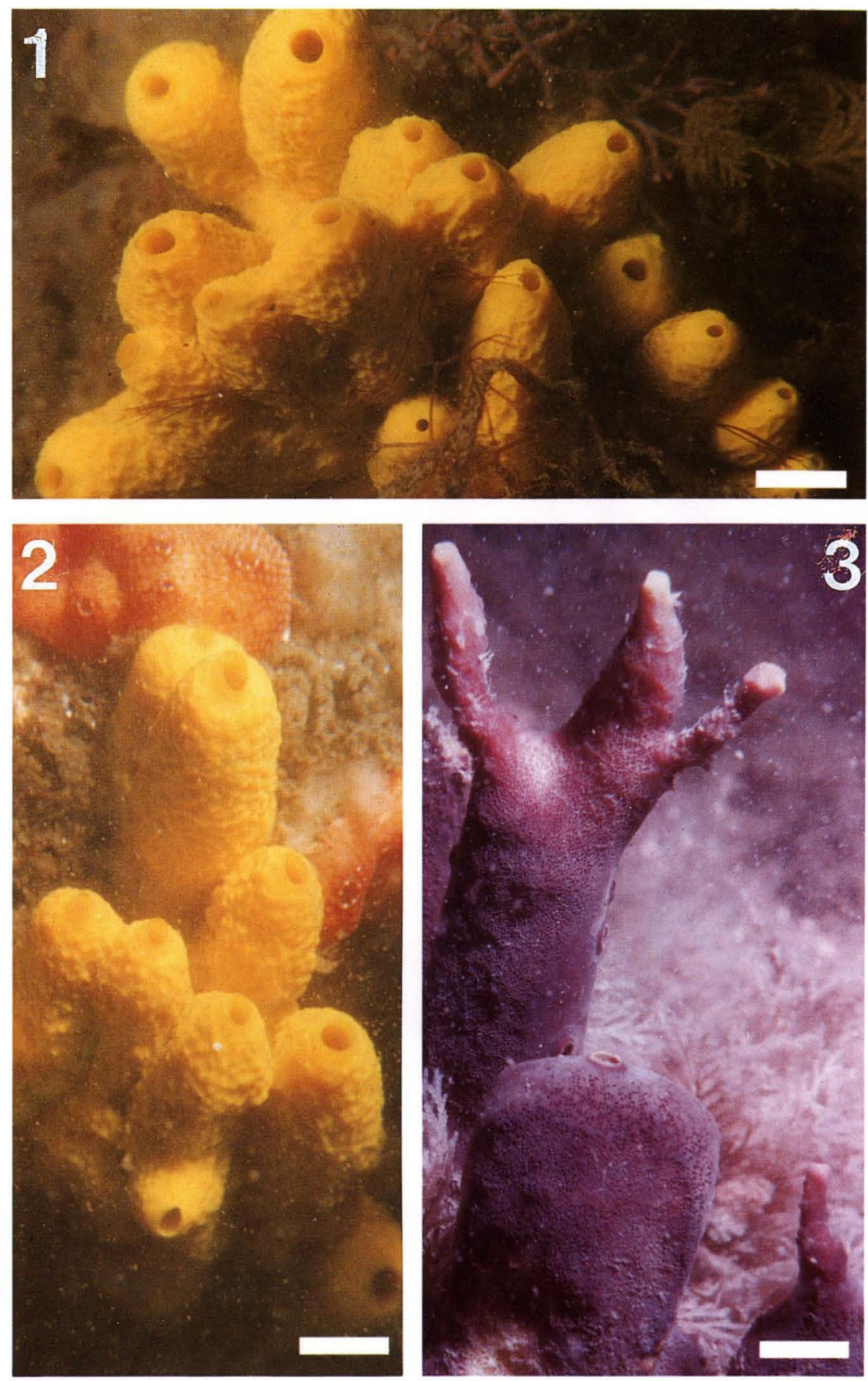

Revta bras. Zool. 18 (Supl. 1): 143 - 160, 2001 

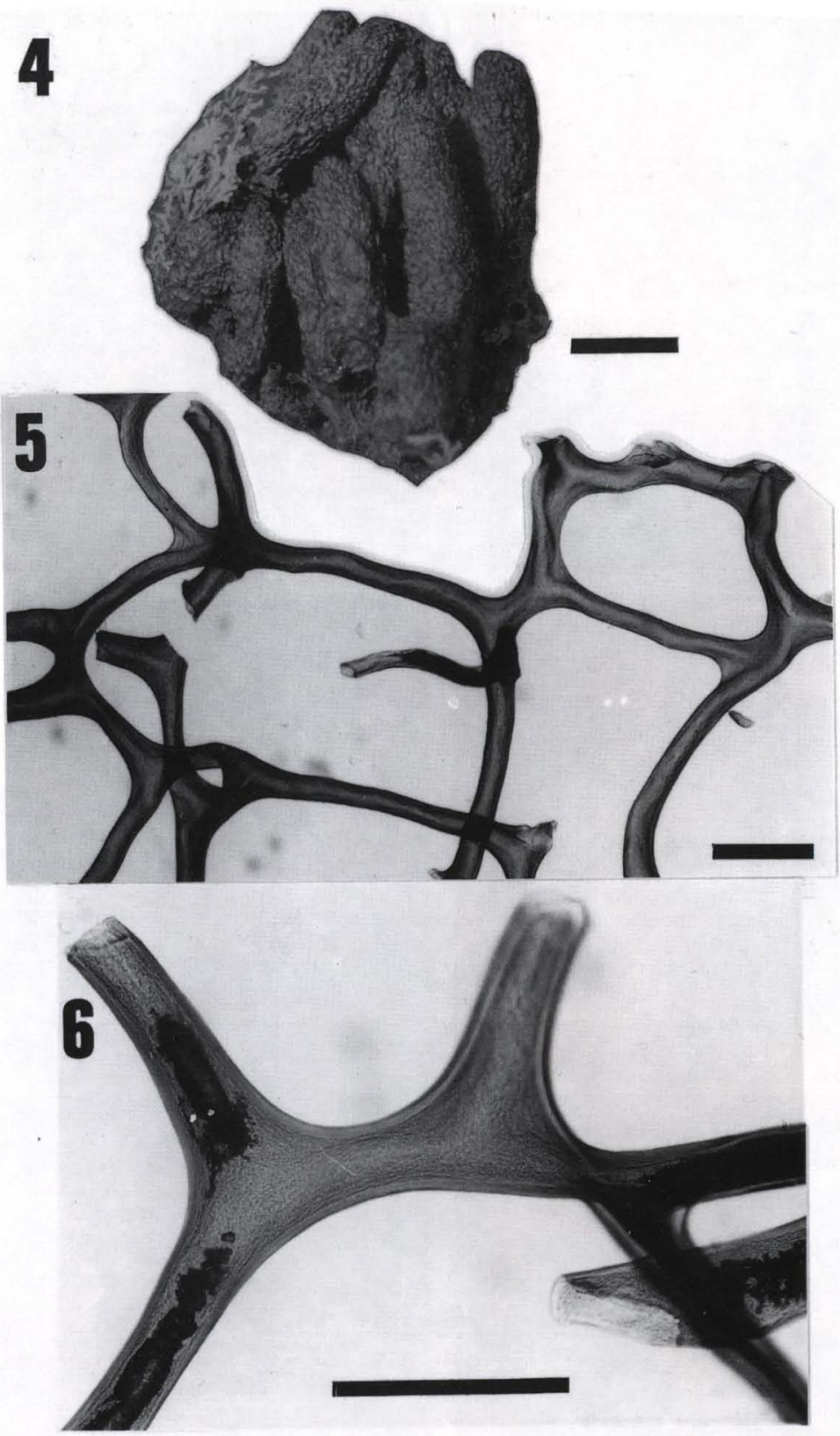

Figs 4-6. Aplysina caissara sp. n. (4) Holotype (MNRJ 1988) after preservation in ethanolscale bar is $1 \mathrm{~cm}$; (5) skeletal architecture (MNRJ 578, paratype); (6) spongin fibres in greater detail (MNRJ 578, paratype) - scale bars are $200 \mu \mathrm{m}$.

Revta bras. Zool. 18 (Supl. 1): 143 - 160, 2001 
which can also be light yellow when small and inhabiting shaded spots (Figs 7, 12), attaign much larger size, and has oscula which are relatively smaller, as well as scattered over its surface (Figs 8, 9,10). Its main colour in the SE Brazilian coastline is, nevertheless, brown/ochre (Figs 9, 10). Another bright yellow species is $A$. lacunosa, a typically large Tropical species which has a general tubular shape with a large pseudoosculum on top, and a fully grooved surface.

Specimens described by Mothes-DE-MorAes (1987) and LERNER (1996) from Santa Catarina State, respectively identified as Aplysina fistularis fulva and $A$. fulva, were reexamined and found to be better ascribed to A. caissara sp. n. on acount of their bright-yellow colour, small dimensions, and apical oscula on digitiform/vulcaniform processes.

\section{Aplysina fulva (Pallas, 1766)}

Figs 7-15, Tab. II

Material studied. MNRJ 357, Ponta do Jarobá (Canal de São Sebastião, São

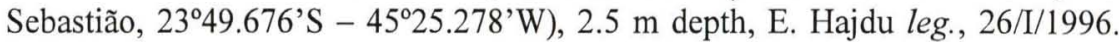
MNRJ 445, Ponta do Jarobá (Canal de São Sebastião, São Sebastião, 23²49.676'S - 4525.278'W), 4 m depth, E. Hajdu leg., 19/II/1997. MNRJ 735, Barequeçaba (Canal de São Sebastião, São Sebastião, 2349.746'S - 4526.478'W), 1 m depth, E. Hajdu leg., 08/I/1996. MNRJ 762, Saco do Poço (Ilha de São Sebastião, Ilhabela, $\left.23^{\circ} 45.658^{\prime} \mathrm{S}-45^{\circ} 14.862^{\prime} \mathrm{W}\right), 8 \mathrm{~m}$ depth, E. Hajdu leg., 09/I/1996. MNRJ 1302,

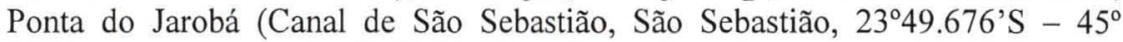
25.278'W), 2 m depth, E. Hajdu leg., 21/XII/1997. MNRJ 1990, rocky coast between Prainha and Praia Brava (“Costão do Navio", São Sebastião, 2350.067'S $\left.-45^{\circ} 29.449^{\prime} W\right), 6$ m depth, E. Hajdu leg., 29/I/1999.

Comparative material. MNRJ 047, Praia do Forno (Arraial do Cabo, RJ). MNRJ 686, Praia das Tartarugas (Búzios, RJ). UFRJPOR 1204, Prainha (Arraial do Cabo, RJ). UFRJPOR 1206, Boqueirão (Arraial do Cabo, RJ). UFRJPOR 2879, Pedra Vermelha (Arraial do Cabo, RJ). UFRJPOR 2917, Pedra Vermelha (Arraial do Cabo, RJ). UFRJPOR 2940, Pedra Vermelha (Arraial do Cabo, RJ). UFRJPOR 2962, Pedra Vermelha (Arraial do Cabo, RJ). UFRJPOR 3582, Urca do Tubarão

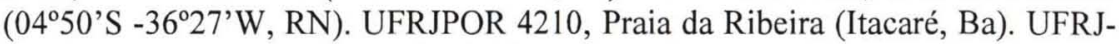
POR 4804, Ilha Rata (Fernando de Noronha Archipelago, PE). UFRJPOR 4819, "Pirapama" shipwreck (off Recife, PE).

Diagnosis. Specimens are more often brownish-yellow (ochre) to purplishbrown ouside, and bright-yellow inside when alive, but yellow specimens do occur. Shape is varied, but cylindrical projections are common (frequently over $15 \mathrm{~cm}$ high), variably thick (frequently over $3 \mathrm{~cm}$ ), with an irregular outline. Oscula are spread over the sponge surface, being only seldom over $3 \mathrm{~mm}$ across, and only seldom aligned.

Description of São Paulo State specimens. Specimens are usually very small, mostly lower than $8 \mathrm{~cm}$, with only one to a few (3-6) digitiform processes. Processes are smooth or slightly conulose, with scattered oscula $(0.5-2 \mathrm{~mm}$ wide $)$, and irregular outlines. Processes are often less than $5 \mathrm{~cm}$ high and $1.5 \mathrm{~cm}$ thick. Anastomoses 
occur. MNRJ 1990 is repent (Fig. 7). Consistency is compressible (cheesy). Live colour varied from bright light-yellow (Fig. 7) to bright-yellow (Fig. 8), turning beije (internally) to brownish-purple (externally) in spirit (Fig. 13).

Skeleton (Tab. II). No ectosomal specialization. Choanosome with a delicate (not so strikingly as in A. caissara sp. n.), irregular tridimensional poligonal network (Fig. 14) of pithed spongin fibres (Fig. 15). After preservation and preparation, fibres are yellow to brown, with a pith which is either of the same colour, or much darker, nearly black. The same specimen may have pith of both colours. Fibres are smooth, straight, curved or undulating.

Table II. Micrometric data for the skeletal architecture of Aplysina fulva (specimens from the study area, the Cabo Frio Region and elsewhere along the northeastern Brazilian Coast). Measures are in $\mu \mathrm{m}$ and $\mathrm{N}=20$, unless stated otherwise.

\begin{tabular}{|c|c|c|c|c|}
\hline Specimen & Locality & $\begin{array}{c}\text { Fibre width: } \\
\text { thinnest - mean - thickest }\end{array}$ & $\begin{array}{l}\text { Pith width: } \\
\text { thinnest - mean - thickest }\end{array}$ & $\begin{array}{l}\text { Mesh area }\left(\mathrm{mm}^{2}\right) \text { : smallest area } \\
\text { (length } x \text { width) }- \text { mean area - } \\
\text { largest area (length } x \text { width) }\end{array}$ \\
\hline MNRJ 357 & Săo Sebastião & $21-\underline{36.0}-48$ & $14-18.2-31$ & $\begin{array}{l}0.14(0.446 \times 0.310)-0.17- \\
0.69(0.941 \times 0.737)\end{array}$ \\
\hline MNRJ 445 & Săo Sebastiăo & $26-\underline{43.3}-77$ & $17-\underline{31.2}-62$ & Not available \\
\hline MNRJ 735 & Săo Sebastião & $36-\underline{46.4}-70$ & $17-\underline{30.5}-53$ & $\begin{array}{l}0.17(0.475 \times 0.359)-0.34- \\
0.44(0.776 \times 0.572)\end{array}$ \\
\hline MNRJ 762 & Ilhabela & $36-\underline{52.9}-77$ & $17-\underline{31.9}-48$ & $\begin{array}{l}0.06(0.252 \times 0.223)-0.32- \\
0.45(0.795 \times 0.563)\end{array}$ \\
\hline MNRJ 1302 & Săo Sebastiăo & $29-\underline{44.1}-67$ & $19-\underline{27.7}-48$ & $\begin{array}{l}0.05(0.310 \times 0.165)-0.23- \\
0.55(0.795 \times 0.698)\end{array}$ \\
\hline MNRJ 1990 & São Sebastiăo & $38-\underline{57,4}-103$ & $24-\underline{39.5}-91$ & $\begin{array}{l}0.31(0.834 \times 0.378)-0.38- \\
0.64(1.067 \times 0.601)\end{array}$ \\
\hline MNRJ 047 & Arraial do Cabo & $43-71.0-101$ & $20-\underline{39.0}-78$ & $\begin{array}{l}0.13(0.367 \times 0.367)-0.43- \\
0.98(1.249 \times 0.784)\end{array}$ \\
\hline MNRJ 686 & Búzios & $43-\underline{53.0}-86$ & $29-\underline{36.0}-63$ & $\begin{array}{l}0.15(0.514 \times 0.294)-0.34- \\
0.83(1.115 \times 0.759)\end{array}$ \\
\hline UFRJPOR 1204 & Arraial do Cabo & $23-\underline{58.8}-78$ & $20-\underline{31.1}-55$ & $\begin{array}{l}0.15(0.620 \times 0.250)-0.47- \\
1.57(1.280 \times 1.230)\end{array}$ \\
\hline UFRJPOR 1206 & Arraial do Cabo & $30-53.4-65$ & $23-31.7-43$ & $\begin{array}{l}0.13(0.450 \times 0.290)-0.37- \\
0.50(0.830 \times 0.600)\end{array}$ \\
\hline UFRJPOR 2879 & Arraial do Cabo & $58-712-85$ & $23-\underline{317}-48$ & $\begin{array}{l}0.21(0.550 \times 0.380)-0.26- \\
0.43(1.010 \times 0.430)\end{array}$ \\
\hline UFRJPOR 2917 & Arraial do Cabo & $40-\underline{58.4}-80$ & $15-24.1-55$ & $\begin{array}{l}0.04(0.260 \times 0.170)-0.23- \\
0.34(0.900 \times 0.380)\end{array}$ \\
\hline UFRJPOR 2940 & Arraial do Cabo & $43-\underline{573}-78$ & $22-36.9-53$ & $\begin{array}{l}0.01(0.120 \times 0.060)-0.03- \\
0.06(0.110 \times 0.510)\end{array}$ \\
\hline UFRJPOR 2962 & Arraial do Cabo & $36-52.6-72$ & $14-22.4-48$ & $\begin{array}{l}0.01(0.175 \times 0.097)-0.16- \\
0.80(1.038 \times 0.776)\end{array}$ \\
\hline UFRJPOR 3582 & $\begin{array}{l}\text { Urca do } \\
\text { Tubarão }\end{array}$ & $52-64.1-87$ & $15-28.9-47$ & $\begin{array}{l}0.04(0.210 \times 0.180)-0.61- \\
0.68(0.890 \times 0.760)\end{array}$ \\
\hline UFRJPOR 4210 & Itacaré & $120-133.6-144$ & $22-\underline{324}-48$ & $\begin{array}{l}0.25(0.553 \times 0.281)-0.32- \\
0.77(1.125 \times 0.689)\end{array}$ \\
\hline UFRJPOR 4804 & $\begin{array}{l}\text { Fernando de } \\
\text { Noronha }\end{array}$ & $50-624-75$ & $18-21.5-28$ & $\begin{array}{l}0.04(0.210 \times 0.210)-0.23- \\
0.57(0.810 \times 0.700)\end{array}$ \\
\hline UFRJPOR 4819 & Recife & $60-131.6-175$ & $20-38.1-102$ & $\begin{array}{l}0.01(0.080 \times 0.070)-0.26- \\
2.15(2.050 \times 1.050)\end{array}$ \\
\hline
\end{tabular}

Figs 7-12. Aplysina fulva, live specimens. (7) Rocky coast between Prainha and Praia Brava ("Costão do Navio"), São Sebastião, SP, ca. 5 m depth - scale bar is $2 \mathrm{~cm}$ long; (8) Praia Preta, São Sebastião Channel, São Sebastião, SP, ca. $3 \mathrm{~m}$ depth - scale bar is $1 \mathrm{~cm}$ long; (9) Búzios, $\mathrm{RJ}$, ca. $3 \mathrm{~m}$ depth - scale bar is $2 \mathrm{~cm}$ long; (10) Búzios, RJ, ca. $3 \mathrm{~m}$ depth - scale bar is 10 cm long; (11) Pedra Vermelha, Ilha de Cabo Frio, Arraial do Cabo, RJ, ca. $3 \mathrm{~m}$ depth - scale bar is $5 \mathrm{~cm}$ long; (12) Ilha da Âncora, Buzios, RJ, ca. $6 \mathrm{~m}$ deep - scale bar is $2 \mathrm{~cm}$ long. 

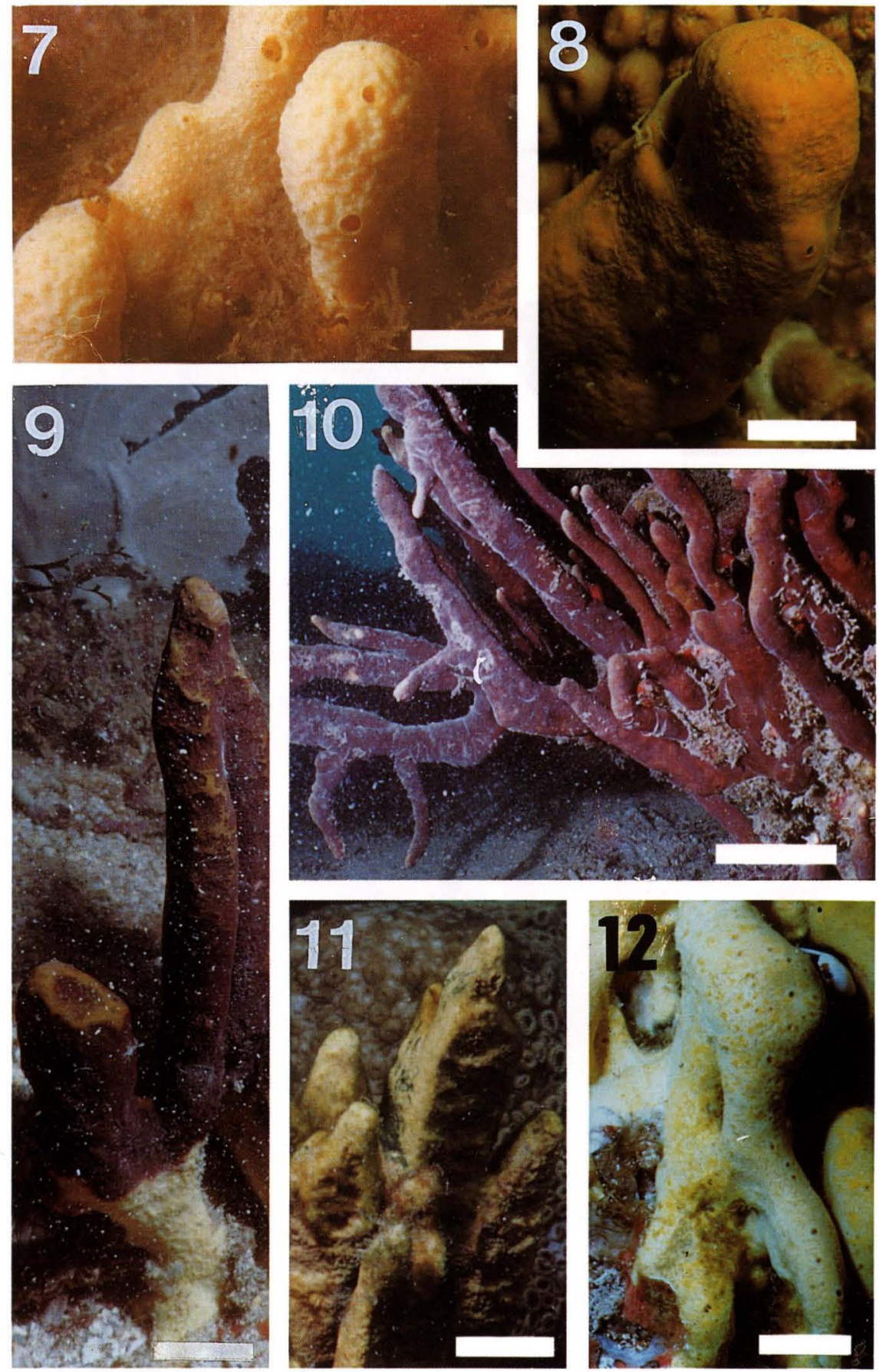

Revta bras. Zool. 18 (Supl. 1): 143 - 160, 2001 


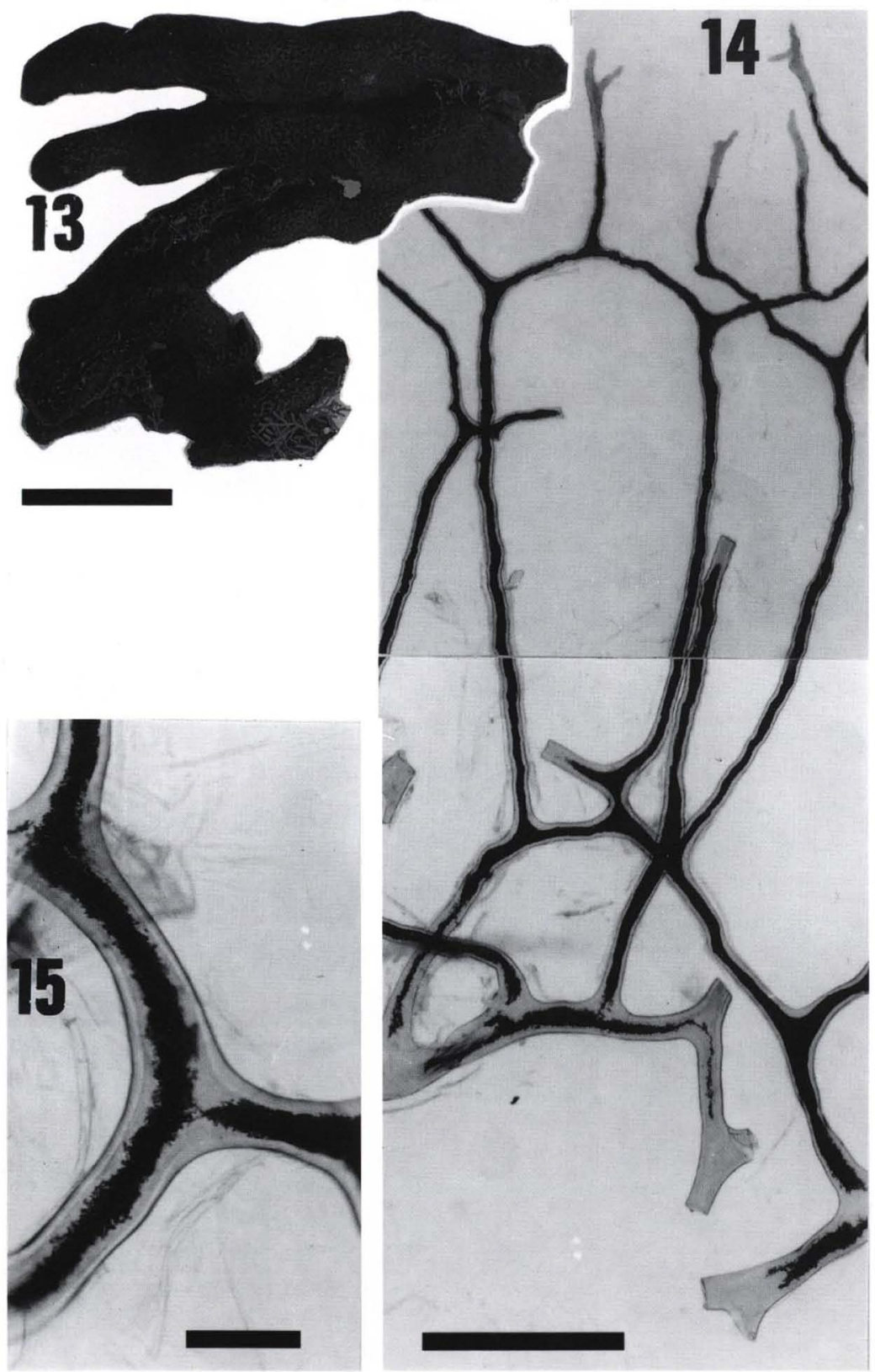

Figs 13-15. Aplysina fulva. (13) Preserved specimen (MNRJ 1990) - scale bar is $2 \mathrm{~cm}$; (14) skeletal architecture (MNRJ 735) - scale bar is $500 \mu \mathrm{m}$; (15) spongin fibres in greater detail (MNRJ 735) - scale bar is $200 \mu \mathrm{m}$.

Revta bras. Zool. 18 (Supl. 1): 143 - 160, 2001 
Ecology. The species is uncommon in the study area, and no dense population has been found in over seventy stations sampled. The largest population appears to be at Praia Preta, where the largest specimens were seen. Specimens tend to be slightly cryptic, frequently with only a small visible portion, the remaining growing underneath medium-sized boulders, or among colonies of the zoanthid Palythoa caribaeorum.

Remarks. Aplysina fulva is the least well dignosed species of the genus in the Tropical southwestern Atlantic. The opposite opinion has been expressed by ZEA (1987), and it may be possible that Caribbean populations appear more clearly set apart, than their southern relatives. In the hope of finding some clearcut diagnostic features for the São Sebastião and Ilhabela populations studied here, specimens from other localities along the Brazilian coast were studied in parallel. Eight specimens from the Cabo Frio region (Arraial do Cabo and Búzios), and four from localities along the northeastern Brazilian coastline were studied. All these were considered typical in the sense that they comprise large, erect, irregularly shaped, massive digits with small oscula spread around. They are all very dark in the fixative, and many of them were reported to be brownish-yellow alive. These broad descriptors fit well with knowledge of Caribbean populations of the species based on extensive in situ observation (e.g. WIEDENMAYER 1977; VAN SOEST 1978; ZEA 1987). The Cabo Frio region is especially important here because an extensive survey of its sponge biota has been conducted by scuba diving during the years 1986 to 1991 (MURICY 1989; MURICY et al. 1991; HAJDU et al. 1992), followed by scattered dives ever since, and Aplysina fulva is perhaps the most conspicuous shallow-water sponge in the area (Figs 9-12; specimens may comprise over 40 digits and spread over $1 \mathrm{~m}$ in diameter; Custódio, unpubl. res.). Contrastingly, specimens in the São Sebastião Channel area are usually small, and frequently bright-yellow (Figs 7-8), which made us hesitating about their correct identification.

Table II clearly show that if a diagnostic feature exists for the Aplysina fulva of the São Sebastião Channel area and its environs, when compared to specimens collected on other localities along the Brazilian coast, it is to be sought in characters other than the morphometry of their spongin network. The only two specimens clearly set apart by the stoutness of their fibres are UFRJPOR 4210 and 4819 , respectively from Itacaré and Recife, which possess fibres over $120 \mu \mathrm{m}$ (mean thickness). Excluding these outsiders, fibres' mean thickness range from 36.0 to $57.4 \mu \mathrm{m}$ in the São Sebastião Channel area populations vs. 52.6 to $71.2 \mu \mathrm{m}$ elsewhere. This difference is not judged enough here to warrant the recognition of a new species. Our decision rests on the fact that only six vs. twelve specimens were studied here (study area vs. the rest of the Brazilian coastline), a certainly meagre database from which to propose a solution based on any sort of statistical approach.

One possibility that must be considered here is that Aplysina fulva, on what is likely to be its austral distribution limit, would have slightly thinner fibres. It is well known that keratose sponges (Orders Dendroceratida, Dictyoceratida and Verongida) have their highest diversity in the tropics and subtropics, being very rare in colder waters (e.g. SARÀ \& VACELET 1973). The waters in the São Sebastião Channel area can be as cold as $13^{\circ} \mathrm{C}$ at the approach of Central South Atlantic Waters (SCHAEFFERNovelli 1990; MigotTo et al. 1993; PIRES-VANIN et al. 1997; Hajdu et al. 1999). 


\section{Aplysina aff. cauliformis}

Figs 3, 16-18, Tab. III

Material studied. MNRJ 1674, rocky coast between Praia Brava and Praia de Toque-Toque (São Sebastião, 235 $\left.50.067^{\prime} \mathrm{S}-45^{\circ} 29.449^{\prime} \mathrm{W}\right), 8 \mathrm{~m}$ depth, E. Hajdu leg., 24/IV/1998. MNRJ 1991, Pedra Montada (Barequeçaba, São Sebastião, $23^{\circ}$ 49.746'S - 45²6.478'W), 4 m depth, E. Hajdu leg., 01/II/1999.

Comparative material. UFRJPOR 4027, Tamandaré, PE. UFRJPOR 4167, Ilha de Santo Aleixo (Serinhaém, PE). UFRJPOR 4190, Viçosa Reef (Nova Viçosa, BA). UFRJPOR 4208, Coroa de Pedra (off Itaparica, BA). UFRJPOR 4285, CE. UFRJPOR 4407, 163'시 $0155^{\prime \prime S}-38^{\circ} 46^{\prime} 1820^{\prime \prime} \mathrm{W}$ (st. C-72, REVIZEE, off BA).

Description. The two specimens collected bear digits of varied morphologies. They can be thin, tapering slightly, dichotomous, reptant; stout, irregular; lobate; or vulcaniform. Protuberances (14) can reach $8 \mathrm{~cm}$ in height (1674), but are mostly smaller than $5 \mathrm{~cm}$ high. Specimen 1991 occupied an area of nearly $600 \mathrm{~cm}^{2}$. Surface is more markedly conulose in specimen 1674 than on 1991, which bear some (nearly) smooth sectors, especially around the oscula. There may be naked portions of the fibrous skeleton sticking out of the sponge in both specimens. Oscula (1-2 $\mathrm{mm}$ in diameter) are spread nearly everywhere. Some alignment (3-6 oscula) is seen in both specimens. Texture is compressible, easily torn. Live-colour ranged from yellow to purple (Fig. 3), and specimen 1991 had still some brown-ochre parts. In spirit they are both deep brownish-purple (Fig. 16).

Skeleton (Tab. III). No ectosomal specialization. Choanosome with a delicate, irregular tridimensional poligonal network (Fig. 17) of pithed (markedly laminated in 1991) spongin fibres (Fig. 18). After preservation and preparation, fibres are yellow to brown, with a pith which is either of the same colour, or much darker, nearly black. The same specimen may have pith of both colours. Fibres are smooth, straight, curved or undulating (seldom).

Ecology. Specimens were associated to algae, tube-worms, ectoprocts and barnacles. They were both growing on light exposed habitats, although light-intensity was not particularly strong due to either water turbidity and/or shadows created by neighbouring erect algae (e.g. Sargassum sp.). They occurred in depths ranging from 4 to $8 \mathrm{~m}$.

Remarks. The two specimens from the São Sebastião Channel area dealt with here sit somewhere between currently available diagnoses for both Aplysina cauliformis and A. fulva. They share with fulva their overall irregular shape with stout irregular protuberances, and dark colour after preservation in ethanol. With cauliformis they share their purplish live colour (Fig. 3, at least tinges of it, as in ZEA 1987 ) and oscula which may be aligned on one side. MNRJ 1674 has a somewhat reptant shape which is more often seen in cauliformis specimens found elsewhere along the Brazilian coastline (Búzios, RJ and Salvador, BA), as well as some slender digits. These specimens were identified as aff. cauliformis to stress that they look very different from those described above under fulva. 


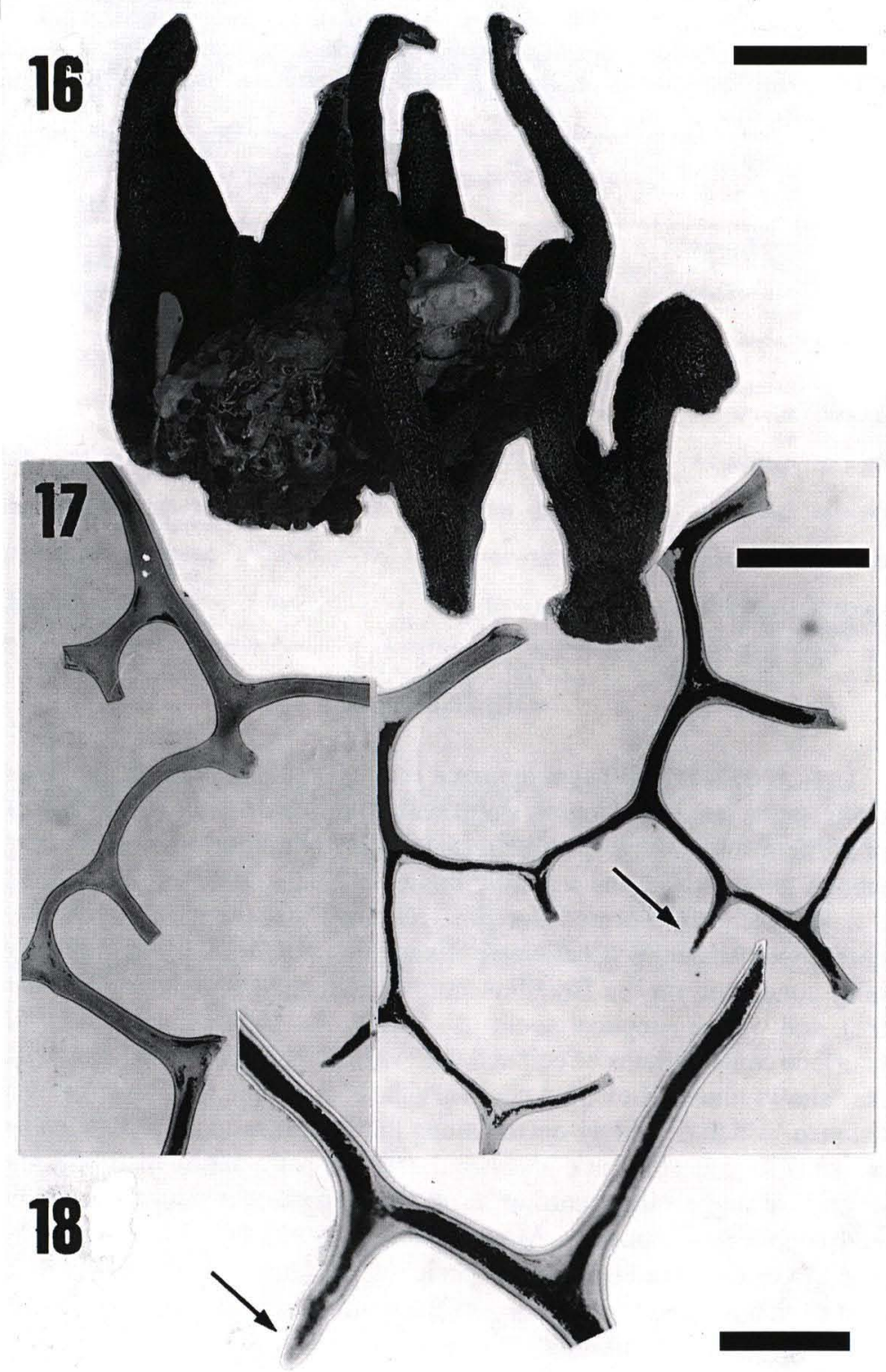

Figs 16-18. Aplysina aff. cauliformis. (16) Preserved specimen (MNRJ 1674) - scale bar is 2 $\mathrm{cm}$; (17) skeletal architecture (MNRJ 1674) - scale bar is $200 \mu \mathrm{m} ;(18)$ spongin fibres (MNRJ $1674)$ - scale bar is $100 \mu \mathrm{m}$. Arrows point to the same fibre, shown under different magnifications. 
Table III. Micrometric data for the skeletal architecture of Aplysina aff. cauliformis (specimens from the study area), Aplysina cauliformis (specimens from the northeastern Brazilian Coast), and Verongia longissima sensu DE LAUBENFELS (1956). Measures are in $\mu \mathrm{m}$ and $N=20$, unless stated otherwise.

\begin{tabular}{|c|c|c|c|c|}
\hline Specimen & Locality & $\begin{array}{l}\text { Fibre width: } \\
\text { thinnest - mean - thickest }\end{array}$ & $\begin{array}{l}\text { Pith width: } \\
\text { Thinnest - mean - thickest }\end{array}$ & $\begin{array}{l}\text { Mesh area }\left(\mathrm{mm}^{2}\right) \text { : smallest area } \\
\text { t (length } \times \text { width) - mean area - } \\
\text { largest area (length } x \text { width) }\end{array}$ \\
\hline MNRJ 1674 & $\begin{array}{l}\text { São Sebastião, } \\
\text { SP }\end{array}$ & $36-\underline{570}-79$ & $24-43.1-60$ & $\begin{array}{l}0.02(0.223 \times 0.087)-0.29- \\
0.45(0.989 \times 0.456)\end{array}$ \\
\hline MNRJ 1991 & $\begin{array}{l}\text { Sắo Sebastiăo, } \\
\text { SP }\end{array}$ & $43-58.6-70$ & $19-\underline{28.6}-46$ & $\begin{array}{l}0.06(0.300 \times 0.200)-0.30- \\
0.50(1.230 \times 0.410)\end{array}$ \\
\hline UFRJPOR 4027 & Tamandaré, PE & $58-101.2-125$ & $12-\underline{24.5}-101$ & $\begin{array}{l}0.04(0.250 \times 0.160)-0.39- \\
0.77(1.000 \times 0.770)\end{array}$ \\
\hline UFRJPOR 4167 & Serinhaen, $P E$ & $43-97.0-134$ & $17-27.0-43$ & Not available \\
\hline UFRJPOR 4190 & $\begin{array}{l}\text { Nova Viçosa, } \\
\text { BA }\end{array}$ & $26-\underline{66.0}-110$ & $12-15.0-74$ & Not available \\
\hline UFRJPOR 4208 & Itaparica, BA & $33-\underline{64.3}-79$ & $21-33.1-50$ & $\begin{array}{l}0.14(0.514 \times 0.281)-0.29- \\
0.52(0.747 \times 0.698)\end{array}$ \\
\hline UFRJPOR 4285 & Ceará & $67-\underline{91.9}-107$ & $20-\underline{31.9}-52$ & $\begin{array}{l}0.01(0.110 \times 0.090)-0.17- \\
0.71(0.910 \times 0.780)\end{array}$ \\
\hline UFRJPOR 4407 & REVIZEE, BA & $47-73.4-90$ & $17-35.2-62$ & $\begin{array}{l}0.08(0.090 \times 0.090)-0.11- \\
0.64(0.860 \times 0.750)\end{array}$ \\
\hline $\begin{array}{l}\text { V. longissima De } \\
\text { Laub., N } N^{\circ} 55009\end{array}$ & Ubatuba, SP & $30-\underline{70.3}-100$ & $18-\underline{35.1}-60$ & $\begin{array}{l}0.23(0.500 \times 0.470)-0.41- \\
0.59(0.90 \times 0.66)(\mathrm{N}=4)\end{array}$ \\
\hline
\end{tabular}

\section{DISCUSSION}

LENDENFELD (1889) synonymized POLEJAEFF's (1884) Brazilian record of Verongia tenuissima (off Alagoas state) with Aplysina archeri, based on reexamination of the former's type specimen. Lendenfeld's description of $A$. archeri does correspond to this species as currently known (e.g. ZEA 1987), so that we trust he could have taken an informed decision. Nevertheless, the species has not been recollected ever since the "Challenger" Expedition (1873-1876), despite extensive dredging conducted on the Brazilian northeastern shelf and slope (1960s to the present), and we are skeptical about its identity. Polejaeff's mention of a "hilly" outer surface could perhaps be equated with VAN SOEST's (1978) statement that the surface "shows much relief", but could also be comparable to what is known from A. lacunosa, which definitely occurs along the Brazilian coast. The "Challenger" station, ca. $730 \mathrm{~m}$ deep, is at odds with the typical bathymetric distribution of the genus, and we suggest the record of $A$. archeri to be kept in doubt until additional material is collected. Recently, MALDONADO \& YOUNG (1998) and LEHNERT \& VAN SOEST (1999) reported on a new species of Aplysina, A. bathyphila Maldonado \& Young, 1998, from deeper waters off the Bahamas and off Jamaica, but records came from 60-150 m depth only.

Aplysina capensis was originally described from South Africa, but neither its assignment to Aplysina, nor the species' occurrence on the Brazilian coast (CE) are well established (HECHTEL 1983). De Laubenfels' material is unavailable, and we cannot verify this record. On biogeographic grounds it can be said that the occurrence of any South African sponge along the Brazilian coast is very unlikely (e.g. Hechtel 1976; van SOEST 1994). The species is diagnosed by its "lettucelike" growth form. 
Aplysina cauliformis was recorded for the Brazilian coast by COLLETTE \& RÜTZLER (1977, off the mouth of the Amazon river) and by MURICY \& MORAES (1998, Tamandaré, PE). We have not reexamined Collette \& Rützler's material, but find it likely that it is correctly identified as the species appears to be widespread along the Brazilian coast. MURICY \& MORAES (1998) record has been reexamined (Tab. III) and found to be correctly identified too, as the sponge is long, erect, slender, with aligned oscula, and the morphometry of its fibre network falls within the range of variation for the species.

Additionally, DE LAUBENFELS (1956) listed Verongia longissima (Carter, 1882) for the Ubatuba area (northern coast of São Paulo state). De Laubenfels based his concept of longissima in its thin digits and inconspicuous colour-change when preserved (DE LAUBENFELS 1948). He considered Aplysina cauliformis a likely synonym of Verongia aurea (Hyatt, 1875) (= Aplysina fulva, in part; fide WIEDENMAYER 1977). WIEDENMAYER (1977) had the opportunity to examine syntypes of both cauliformis and longissima, and considered the former a good species of Aplysina, transfering the latter to the synonymy of Spinosella tenerrima (Duchassaing \& Michelotti, 1864) (= Callyspongia tenerrima; fide VAN SOEST 1980). We had the opportunity to examine a microscopic slide from De Laubenfels' brazilian material and found it to pertain to Aplysina. This specimen do not conform to the type material of Verongia longissima (= Callyspongia), but rather, seem close to HECHTEL's (1965) interpretation of the species (= Aplysina cauliformis sensu WIEDENMAYER 1977). In the absence of any descriptive data on the specimen itself it is, nevertheless, impossible to assign his record with confidence to either A. cauliformis or A. fulva. DE LAUBENFELS' $(1936,1948)$ concept of Verongia aurea was based on a misconception, as Spongia fulva Pallas, 1766 is not a synonym of $S$. officinalis Linnaeus, 1759 (WIEDENMAYER 1977), and is rather a valid Aplysina species. In summary, DE LAUBENFELS (1936, 1948) considered what is currently understood as A. cauliformis (e.g. V. longissima HeCHTEL 1965; A. cauliformis sensu VAN SOEST 1978; ZEA 1987) as a likely junior synonym of $A$. fulva. Opinions expressed in the recent literature are followed (e.g. WIEDENMAYER 1977; VAN SOEST 1978; ZEA 1987), that both species can be recognized as separate.

Aplysina fistularis was recorded for the Brazilian coast by DE LAUBENFELS (1956), HECHTEL (1976, as Verongia f.), and COLLETTE \& RÜTZLER (1977, as $V$. $f$. forma $f$.). None of these specimens have been reevaluated here, but the species is known to occur at Abrolhos (BA; Muricy, pers. comm.; underwater photograph), and is thus a confirmed record for the Brazilian coast. Indeed, it is quite possible that its type locality is located somewhere along this coastline, as ESPER (1794) referred to it as originary from the "American Coast of South Atlantic" (apud LENDENFELD 1889). MURICY's (1989) record of the species is here ascribed to Aplysina fulva, on the basis of reexamination of an extensive series of specimens collected at Arraial do Cabo (RJ; Tab. II, and additional material in the UFRJPOR collection), on which he based his record. Aplysina fulva, as discussed above, is widespread along the Brazilian coast. It has been cited by JoHNSON (1971, as Verongia f.; CE), COLLETTE \& RÜTZLER (1977, as V. fistularis forma fulva, off the 
mouth of the Amazon river), SoLÉ-CAVA et al. (1981, as A. fistularis forma fulva, ES), Muricy et al. (1991, 1993, RJ) and Mothes \& BASTIAN (1993, Fernando de Noronha Archipelago, PE). MothES-DE-MoRAES's (1987, SC) and LERNER's $(1996$, SC) records were reevaluated and ascribed to the new species described above, Aplysina caissara sp. n. Thus, the occurrence of Aplysina fulva at localities farther south than those studied here remains to be established.

Aplysina janusi (originally as Verongia; syntype restudied, MNHN-LBIMNBE 1026) is transferred here to Aiolochroia Wiedenmayer, 1977 (Druinellidae, Verongida, Demospongiae), being possibly conspecific with A. crassa (Hyatt, 1875). The picture provided by BoURY-ESNAULT (1973, PI. III, fig. 3 ) is a bit odd, as a tubular shape has not been reported for A. crassa, from Brazil at least, yet. The picture reminds of a Callyspongia (Callyspongiidae, Haplosclerida, Demospongiae) instead.

Aplysina lacunosa was quoted cryptically by HECHTEL (1983). This would be the correct identification for his Verongia sp. a (HECHTEL 1976). Aplysina lacunosa is confirmed here as occurring along the Brazilian coast, on the basis of recently collected material deposited in the MNRJ (1504) and UFRJPOR (4429) collections.

Other records of Aplysina longissima for the Brazilian coast were carried out by JOHNSON (1971) and HECHTEL (1976), both as Verongia longissima. Both these records are here ascribed to A. cauliformis. As explained above, longissima is unavailable for species of Aplysina, as its type specimen was found to be conspecific to Callyspongia tenerrima. JoHnSON's (1971) record is suspect as the oscula were reported to be spread around the branches, and no live colour was known, so that the identification rests mostly on the ramose, cylindrical habit, which is definitely to be found among A. fulva specimens too. HECHTEL (1976) did not describe his specimens, but from his earlier taxonomic treatment (HECHTEL 1965; Jamaican sponges) we tend to believe in his identification.

Aplysina pergamentacea was described from Piedade (near Recife, PE). It has a compressed lamellate shape with oscula situated mostly on the rims (HECHTEL 1983). Its habit does appear unique and the species appears valid. Study of additional specimens will establish how trustworthy these characters are. Confidence in the new species described above, A. caissara sp. n., stems in great part from the large series of specimens observed in situ.

As mentioned above, Aplysina tenuissima (as Verongia), recorded for the Brazilian coast by POLEJAEFF (1884), has been transferred to $A$. archeri by LENDENFELD (1889), but we are uncertain about the correct identification of the specimen. Since HYATT's (1875) original record has been transferred too, and as the name tenuissima has never been used again, it appears wise to consider Polejaeff's record as a dubious archeri, rather than a dubious tenuissima.

Given the rationale above, an ammended list of species of Aplysina occurring along the Brazilian coastline is as follows: A. caissara sp. n., A. cauliformis, A. fistularis, A. fulva, A. lacunosa, and A. pergamentacea. Aplysina archeri and $A$. capensis are dubious records. 
ACKNOWLEDGEMENTS. Authors are thankful to Klaus Rützler \& Kate Smith for the extended loan of DE LAUBENFELS' (1956) slide collection (Smithsonian Institution, Washington D.C., E.U.A.); and to Beatriz Mothes and Cléa B. Lerner (MCN) for the loan of material from Santa Catarina State. Paulo A.S. Mourão and Mauro Pavão (Universidade Federal do Rio de Janeiro) are thanked for the provision of papain, and G. Lôbo-Hajdu (Universidade do Estado do Rio de Janeiro) for the preparation of all the buffers/solutions needed for our enzimatic treatment of spongin skeletons. $\mathrm{CNPq}$ is thanked for a Research Productivity Fellowship to $\mathrm{EH}$. FAPERJ is thanked for a Scientific Iniciation Fellowship to USP, and a research grant to EH. FAPESP provided research grants and a Post-Doc Fellowship to EH. FUJB is thanked for grants awarded to the Departamento de Invertebrados (Museu Nacional).

\section{REFERENCES}

BERGQUIST, P.R. 1980. The ordinal and subclass classification of the Demospongiae (Porifera); appraisal of the present arrangement, and proposal of a new order. New Zealand Jour. Zool. 7 (1): 1-6.

Bergquist, P.R. \& R.J. Wells. 1983. Chemotaxonomy of the Porifera: the development and current status of the field, p. 1-50. In: P. Scheuer (Ed.). Marine Natural Products Pt. 5. New York, Academic Press, 383p.

Boury-Esnault, N. 1973. Campagnes de la Calypso au large des côtes atlantiques de l'Amerique du Sud (1961-1962). I. 29. Spongiaires. Rés. Scient. Camp. Calypso 10: 263-295.

Collette, B.B. \& K. Rutzler. 1977. Reef fishes over sponge bottoms off the mouth of the Amazon River. Proc. $3^{\text {rd }}$ Int. Coral Reef Syp., p. 305-310.

DE LAubenfels, M.W. 1936. A discussion of the sponge fauna of the Dry Tortugas in particular and the West Indies in general, with material for a revision of the families and orders of the Porifera. Pap. Tortugas Lab. 30: 1-225.

1948. The order Keratosa of the Phylum Porifera. A monographic study. Occas. Papers Allan Hancock Found. 3: 1-217.

1956. Preliminary discussion of the sponges of Brazil. Contr. Avulsas Inst. Oceanogr.

Univ. São Paulo, Oceanogr. Biol. 1: 1-4.

ESPER, E.J.C. 1794. Die Pflanzenthiere. Theil I. Abbildungen nach der Natur mit Farben erleuchtet, nebst Beschreibungen. Nürnberg, Raspe, 303p.

HAJDU, E. 1998. Lista dos poríferos (Phylum Porifera) marinhos citados para o Estado de São Paulo - Novembro de 1997. Base de Dados do BIOTA: http://www.biota.org.br/biodiv/ biodiversidade/poriferos/porifera.

Hajdu, E.; G. Muricy, M. Custódio; C. Russo \& S. Peixinho. 1992. Geodia corticostylifera (Demospongiae, Porifera) new Astrophorid from the Brazilian coast (Southwesten Atlantic). Bull. mar. Sci. 51 (2), 204-217.

Hajdu, E.; G. Muricy; R.G.S. Berlink \& J.C. Freitas. 1996. Marine poriferan diversity in Brasil: through knowledge to management, p. 157-172. In: C.E.M. Bicudo \& N.A. MENEzES (Eds). Biodiversity in Brazil: a first approach. São Paulo, CNPq, 326p.

Hajdu, E.; R.G.S. Berlink \& J.C. Freitas. 1999. Porifera, p. 19-32. In: A.E. Migotto \& C.G. Tiago (Eds). Biodiversidade do Estado de São Paulo, Brasil (3): Invertebrados Marinhos. São Paulo, Fundação de Amparo à Pesquisa do Estado de São Paulo, 310p.

Hechtel, G.J. 1965. A systematic study of the Demospongiae of Port Royal, Jamaica. Bull. Peabody Mus. nat. Hist. 20: 1-94.

1976. Zoogeography of brazilian marine Demospongiae, p. 237-259. In: F.W. HARRISON \& R.R. Cowden (Eds). Aspects of sponges biology. New York, Academic Press, IV+354p.

1983. New species of marine Demospongiae from Brazil. Iheringia, sér. Zool., 63: 59-89.

HyatT, 1875. Revision of the North-American Porifera, with remarks upon foreign species. Part. I. Boston Soc. nat. Hist. Mem. 2: 399-408.

Revta bras. Zool. 18 (Supl. 1): 143 - 160, 2001 
JoHnson, M.F. 1971. Some marine sponges of northeast Brazil. Arq. Ciênc. Mar. 2 (11): 103-116.

LEHNERT, H. \& R.W.M. VAN SOEST. 1999. More north Jamaican deep fore-reef sponges. Beaufortia 49 (12): 141-169.

LENDENFELD, R.L. 1889. A monograph of the horny sponges. London, Trübner \& Co., IV+936p.

Lerner, C.B. 1996. Esponjas da Ilha da Galé, Reserva Marinha Biológica do Arvoredo, Santa Catarina, Brasil (Porifera, Demospongiae). Biociências, Porto Alegre, 2 (4): 101-129.

MALDONADO, M. \& C.M. YounG. 1998. Reevaluation of stalked aplysinid sponges, with description of a new species from the upper Bahamian slope. Bull. Mar. Sci. 63 (2): 417-426.

Migotto, A.E.; C.G. Tiago \& A.R.M. MAGALHÃES. 1993. Malacofauna marinha da região costeira do Canal de São Sebastião, SP, Brasil: Gastropoda, Bivalvia, Polyplacophora e Scaphopoda. Bol. Inst. Oceanogr. Univ. São Paulo 41 (1/2): 13-27.

Mothes-DE-MoraEs, B. 1987. Ocorrência de poríferos na zona de maré da Ilha João da Cunha, Porto Belo, Santa Catarina, Brasil (Porifera, Demospongiae). I. Iheringia, sér. zool., 66: 129-139.

Mothes, B. \& M.C.K.A. BAsti^N. 1993. Esponjas do Arquipélago de Fernando de Noronha (Porifera, Demospongiae). I. Iheringia, sér. zool., 75: 15-31.

MuriCY, G. 1989. Sponges as pollution-biomonitors at Arraial do Cabo, Southeastern Brazil. Rev. Brasil. Biol. 49 (2): 347-354.

Muricy, G.; E. Hajdu; M. Custódio; M. Klautau; C. Russo \& S. Peixinho. 1991. Sponge distribution at Arraial do Cabo, S.E. Brazil. Proc. VII Symp. Coast. Ocean Manag., ASCE Publs, 2, p. 1183-1196.

Muricy, G.; E. Hajdu; F.V. Araujo \& A.N. Hagler. 1993. Antimicrobial activity of Southwestern Atlantic shallow-water marine sponges (Porifera). Sci. Mar. 57 (4): 427-432.

Muricy, G. \& F.C. Morais. 1998. Marine sponges of Pernambuco State, NE Brasil. Rev. Brasil. Oceanogr. 46 (2): 213-217.

Pires-Vanin, A.M.S.; T.N. Corbisier, E. Arasaki \& A.M. Möellmann. 1997. Composição e distribuição espaço-temporal da fauna bêntica no Canal de São Sebastião. Relat. Téc. Inst. Oceanogr. 41: 29-46.

PolÉJAEFF, N.N. 1884. Report on the Keratosa collected by H.M.S. Challenger during the years 1873-1876. Rep. sci. Res. Voyage Challenger. 2: 1-88.

SARÀ, M. \& J. VACELet, 1973. Écologie des Demosponges, p. 462-576. In: P.P. Grassé (Ed.). Traité de Zoologie. Paris, Masson, VI+716p.

SCHAefFer-Novel.., Y. 1990. Vulnerabilidade do litoral norte do estado de São Paulo a vazamentos de petróleo e derivados. An. II Simp. Ecoss. Costa Sul e Sudeste brasil., Estrutura, Função e Manejo, p. 375-399.

Solé-Cava, A.M.; A. Kei.ecom \& G.J. KanNEngiesser. 1981. Study of some sponges (Porifera, Demospongiae) from the infralitoral of Guarapari, Espirito Santo, Brazil. Iheringia, sér. zool., 60: 125-150.

VAN SoEst, R.W.M. 1978. Marine sponges from Curaçao and other caribbean localities. Part I. Keratosa. Stud. Fauna Curaçao Caribb. Isls. 56 (179): 1-94.

1980. Marine sponges from Curaçao and other caribbean localities. Part II. Haplosclerida. Stud. Fauna Curaçao Caribb. Isls. 62 (191): 1-173.

1994. Demosponge distribution patterns, p. 213-223. In: R.W.M. vAN SOEST; T.M.G. vAN Kempen \& J.C. BRACKMAN (Eds). Sponges in time and space: Biology, Chemistry, Palentology. Rotterdam, Balkema, 515p.

WiEDENMAYER, F. 1977. Shallow-water sponges of the western Bahamas. Basel, Birkhäuser Verlag, $287 \mathrm{p}$.

ZEA, S. 1987. Esponjas del Caribe Colombiano. Santa Marta, Editorial Catálogo Científico, 286p.

Recebido em 11.V.2000; aceito em 22.V1.2001. 